\title{
JAKs and STATs in chemoresistance
}

\author{
Ana Costa-Pereira \\ From 16th International Charles Heidelberger Symposium on Cancer Research \\ Coimbra, Portugal. 26-28 September 2010
}

Many cancer patients develop resistance to chemotherapeutic drugs and this results in elevated mortality. Understanding the mechanisms that mediate drug resistance is critical to develop novel therapeutic strategies. Fibroblast growth factor (FGF)-2, which leads to the formation of a B-RAF/PKCE/S6K2 multi-protein complex, plays a key role in chemoresistance. This enhances the selective translation of anti-apoptotic proteins such as BCL-2 and IAP family members and protects cells from death induced by chemotherapy in several cancer types. We have been investigating the role of Janus kinases (JAKs) and signal transducers and activators of transcription (STATs), most notably known for their pivotal roles in mediating cytokine and immune responses, in FGF-2-mediated chemoresistance. The participation of JAKs in drug resistance pathways and the implications of using inhibitors to these kinases in cancer multi-target therapies will be discussed.

Published: 24 September 2010

Cite this article as: Costa-Pereira: JAKs and STATs in chemoresistance.

BMC Proceedings 2010 4(Suppl 2):O15.

Correspondence: a.costa-pereira@imperial.ac.uk

Division of Cancer, Department of Surgery and Cancer, Faculty of Medicine,

Imperial College, London, UK and Hammersmith Hospital, London, UK
Submit your next manuscript to BioMed Central and take full advantage of:

- Convenient online submission

- Thorough peer review

- No space constraints or color figure charges

- Immediate publication on acceptance

- Inclusion in PubMed, CAS, Scopus and Google Scholar

- Research which is freely available for redistribution 